\title{
Damage and recovery of Photosystem II during a manipulative field experiment on solar bleaching in the coral Goniastrea aspera
}

\author{
B. E. Brown ${ }^{1, *}$, R. P. Dunne ${ }^{1}$, M. E. Warner ${ }^{2}$, I. Ambarsari ${ }^{1}$, W. K. Fitt ${ }^{2}$, S. W. Gibb ${ }^{3}$, \\ D. G. Cummings ${ }^{3}$ \\ ${ }^{3}$ Department of Marine Sciences and Coastal Management, University of Newcastle, Newcastle upon Tyne NE1 7 RU, \\ United Kingdom \\ ${ }^{2}$ Institute of Ecology, University of Georgia, Athens, Georgia 30602, USA \\ ${ }^{3}$ Plymouth Marine Laboratory, Prospect Place, The Hoe, Plymouth, Devon PL1 3DH, United Kingdom
}

\begin{abstract}
The solar radiation regime on differently oriented surfaces of the shallow-water coral Goniastrea aspera is markedly different. Field experiments involving rotation of small (20 cm diameter) hemispherical colonies exposed hitherto protected surfaces of the colonies to high levels of photosynthetically active radiation (PAR) whilst reducing PAR on the opposite surface. Photodamage and recovery, respectively, were recorded in the symbiotic algae using non-invasive chlorophyll fluorescence techniques. Measurements of photochemical efficiency $\left(F_{v} / F_{\mathrm{m}}\right)$ indicated that the Photosystem II (PSII) reaction centres of algae in previously protected surfaces suffered 'chronic' photoinhibition, probably on a timescale of $3 \mathrm{~h}$, as a result of exposure to elevated solar PAR. Furthermore, evidence from this study corroborates earlier findings that this photodamage is a function of high PAR irradiance for short periods rather than a similar dose accumulated more slowly. Simultaneously, algae on the opposite surfaces were observed to recover their photochemical efficiency, but this recovery was at a much slower rate involving several days at reduced PAR. The photodamage was sufficiently severe to lead to the formation of visible lesions (bleached areas). Observations of coral polyp retraction and measurements of the protective xanthophyll pigments in the algae showed behavioural and photoprotective mechanisms being deployed to mitigate the photodamage.
\end{abstract}

KEY WORDS: Photodamage - Photoprotection - Xanthophylls - Corals - Bleaching - Symbiotic dinoflagellates

\section{INTRODUCTION}

Solar bleaching in corals is widespread on shallow intertidal reef flats throughout the tropics, having been observed on the west coast of Thailand (Brown et al. 1994a), in the western Pacific (Buskirk et al. 1981), in Okinawa, Japan (Van Woesik pers. comm.), the Great Barrier Reef, Australia (Kleypas pers. comm.), the west coast of Malaysia, the Andaman Islands, and Banda Neira in eastern Indonesia (Brown unpubl). This type of bleaching manifests itself as colourless lesions on the surface of coral colonies facing the direct solar

•E-mail: 101515.1267@compuserve.com beam, and is caused by exposure to high levels of photosynthetically active radiation ( $\mathrm{PAR}_{i} 400$ to $700 \mathrm{~nm}$ ) (Brown et al. 1994a). It involves a loss of symbiotic algae and, in some cases, algal chlorophyll. (Le Tissier \& Brown 1996, Ambarsari et al. 1997).

Extensive worldwide bleaching of corals during the last 2 decades has been attributed to the combined effects of elevated sea temperature and high solar radiation, with high sea temperature making corals more susceptible to the damaging effects of solar radiation (Brown 1997). While solar bleaching and temperature-induced bleaching may be elicited by subtly different combinations of stressors, it is likely that the underlying mechanism of bleaching is essentially similar in both cases. Recent work has shown that photo- 
synthetic systems (particularly Photosystem II [PSII]) are a principal target for damage in corals subjected to experimentally induced sea-temperature elevations (Iglesias-Prieto et al. 1992, Warner et al. 1996, Jones et al. 1998). Damage occurs when the photoprotective defences of the coral are exceeded. Such defences include xanthophyll cycle pigments which act to dissipate excess photon energy as heat (Ambarsari et al. 1997, Brown et al. 1999); anti-oxidant enzymes (Lesser et al. 1990, Lesser 1997), $\beta$-carotene production (Ambarsari et al. 1997), host pigmentation (Dove et al 1995), mycosporine-like amino acids (Dunlap \& Shick 1998), and behavioural responses such as coral tissue retraction (Yonge 1940, Brown et al. 1994b).

This study used chlorophyll fluorescence measurements to track changes in photosynthetic efficiency of the coral Goniastrea aspera during a manipulative field experiment when solar bleaching was induced. G. aspera is common in intertidal habitats but also occurs subtidally, often in very protected turbid environments (Veron 1986). The experiment aimed to evaluate the relative responses of differently oriented surfaces of the coral to natural solar radiation. Measurements of light harvesting and photoprotective pigments were also made in order to supplement information on the photosynthetic status of coral symbiotic algae.

\section{MATERIALS AND METHODS}

The study site at Phuket Thailand $\left(7^{\circ} 50^{\prime} \mathrm{N}, 98^{\circ} 25.5^{\prime} \mathrm{E}\right)$, factors responsible for solar bleaching, the temporal progression of bleaching, and the significance of carotenoid pigments as a photoprotective defence have been described in detail by Brown et al. (1994a), Le Tissier \& Brown (1996), Ambarsari et al. (1997), and Brown et al. (1999).

Over the spring-tide period 26 to 31 January 1998 , solar bleaching of colonies of Goniastrea aspera at the study site was predicted to occur from analysis of tidal predictions and sun angles. However, on our arrival at the field site in early January, intertidal corals already showed solar lesions on their western surfaces. This bleaching was earlier than expected, and was probably the result of lower than normal tides due to negative sea-level anomalies in the eastern Indian Ocean in late December 1997, coincident with the major El Niño of that year (Chambers et al. 1999).

On 15 January 1998, at the end of the spring-tide period preceding the predicted solar bleaching, 25 coral colonies of approximately $20 \mathrm{~cm}$ in diameter were carefully detached from the reef using a hammer and stone-chisel and rotated $180^{\circ}$ before being cemented in position. An additional 25 colonies were detached from the reef and then replaced in their original position to act as handling controls. All colonies were tagged for future identification. As a result of the manipulation, former east surfaces now faced west and vice versa in rotated colonies. For ease of comparison in discussing results, the sides of rotated corals will be described as 'west' (i.e. former east) and 'east' (i.e. former west), while the sides of control or non-manipulated corals will be described as west and east. Sampling for fluorescence and pigment analysis effectively used 6 coral colonies per sampling time. Other tagged colonies were lost or dislodged between rotation and sampling.

On the reef flat, at the same height as the coral colonies, 3 matched PAR $2 \pi$ cosine corrected quantum sensors (Macam Photometrics SD101QV-Cos) were orientated horizontally, and at $45^{\circ}$ to the vertical, to record PAR (400 to $700 \mathrm{~nm}$ ) received by top, east and west facing coral surfaces over the period 13 January to 3 February 1998. Above-water downwelling irradiance was also measured simultaneously using a similar PAR sensor at Phuket Marine Biological Center, $1.5 \mathrm{~km}$ away from the study site. Irradiances were recorded at 1 min intervals. All sensors were cross-calibrated using a scanning spectroradiometer under clear sky conditions on 4 February 1998. Reef flat sensors were cleaned twice daily, and underwater readings were corrected for the 'immersion effect' (Tyler \& Smith 1970).

On 26, 28 and 30 January, 3 control and 3 rotated coral colonies were removed from the reef flat and taken to the laboratory in the afternoon, as soon as the tide receded from them, for measurement of chlorophyll fluorescence. Analysis was carried out using a pulse amplitude fluorescence system (PAM 101, 103 Walz Effeltrich, Germany). Both effective quantum yield $\left(\Delta F / F_{\mathrm{m}}\right.$ ' where $\Delta F=$ saturation pulse-induced fluorescence increase, and $F_{\mathrm{m}}$ = maximal chlorophyll fluorescence yield in light-adapted state) and photochemical efficiency $\left(F_{\mathrm{v}} / F_{\mathrm{m}}\right.$ where $F_{\mathrm{v}}=$ maximal variable fluorescence yield, and $F_{\mathrm{m}}=$ maximal chlorophyll fluorescence yield in dark-adapted state) of PSII were recorded as described by Warner et al. (1996) and Brown et al. (1999). Quantum yield was measured in rotated colonies within $30 \mathrm{~min}$ of collection from the reef. Photochemical efficiency was measured in both rotated and control colonies 6 to $12 \mathrm{~h}$ after collection to allow full recovery of PSII from the effects of dynamic photoinhibition. During this period of overnight recovery, corals were maintained in flow-through seawater aquaria supplied with additional aeration. Chlorophyll fluorescence measurements were taken from east and west surfaces in both control and rotated corals, as well as from $1 \mathrm{~cm}$ interval points that spanned a $180^{\circ}$ arc from the existing solar lesion on the west side to the opposite eastern surface of control coral colonies. At 
the times of measurement, polyp contraction appeared uniform over the whole surface of the colony.

Pigment measurements were also taken from cores extracted in the field from east and west facing surfaces of 3 control and 3 rotated coral colonies on 26, 28 and 30 January. Cores were taken from coloured coral tissues and not from lesion areas; where lesions were present, the cores were drilled from coloured tissues adjacent to the lesion. Algal pellets were prepared and pigments analysed by high performance liquid chromatography (HPLC) as described in Ambarsari et al. (1997) and Brown et al. (1999).
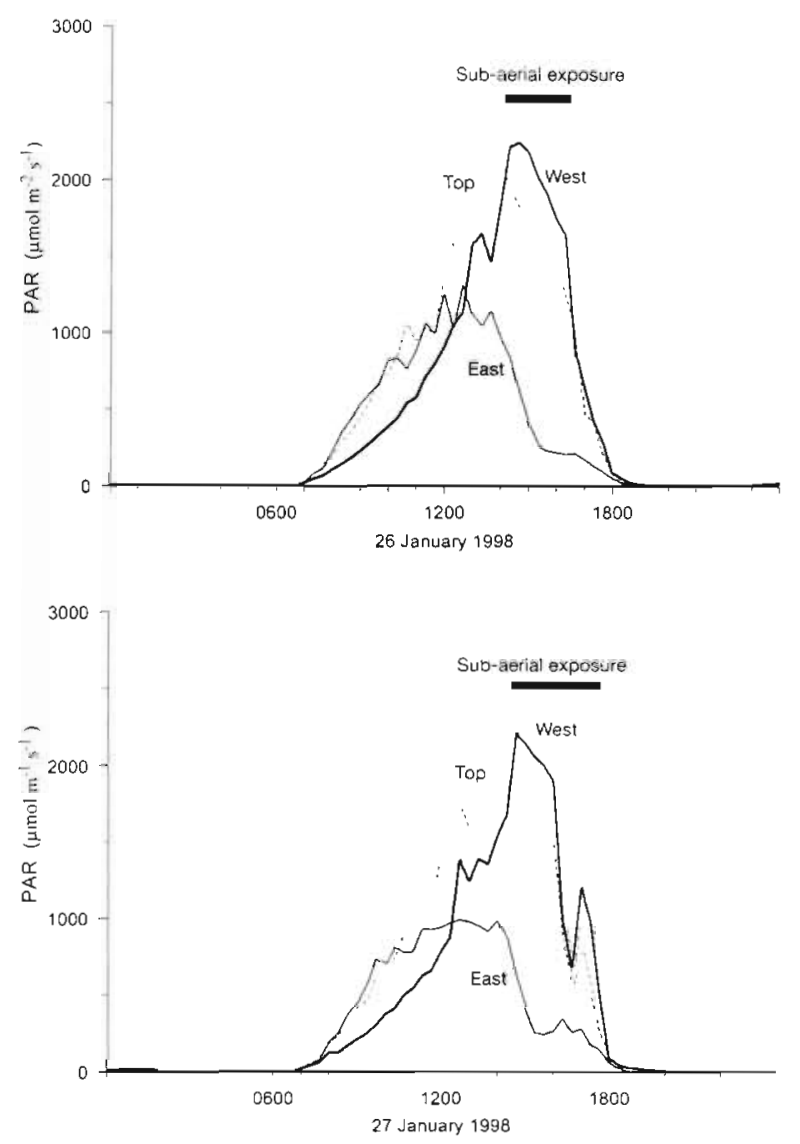

Fig. 1. Solar PAR irradiance $\left(\mu \mathrm{mol} \mathrm{m} \mathrm{m}^{-2} \mathrm{~s}^{-1}\right)$ at the study site 26 to 30 January 1998. Records from the reef flat sensors (west, top, and east surfaces of the colonies) have been smoothed with a 30 min filter to remove the momentary 'flashes' which occur underwater The lightly shaded area represents the record of the above-water downwelling PAR irradiance. Periods when the corals were above water during daylight hours (sub-aerial exposure) are shown by bars above the plots

\section{RESULTS}

\section{Solar radiation}

As Fig. 1 shows, the dates of 26, 27, 29 and 30 January were almost clear sky days with very little or only occasional cloud. On 28 January, the day was very cloudy and irradiance was considerably reduced. During clear sky days, when corals were sub-aerially exposed, high PAR irradiance was experienced on the west sides of corals compared to the east sides. Maximum irradiances in excess of $2200 \mu \mathrm{mol} \mathrm{m} \mathrm{m}^{-2} \mathrm{~s}^{-1}$ were
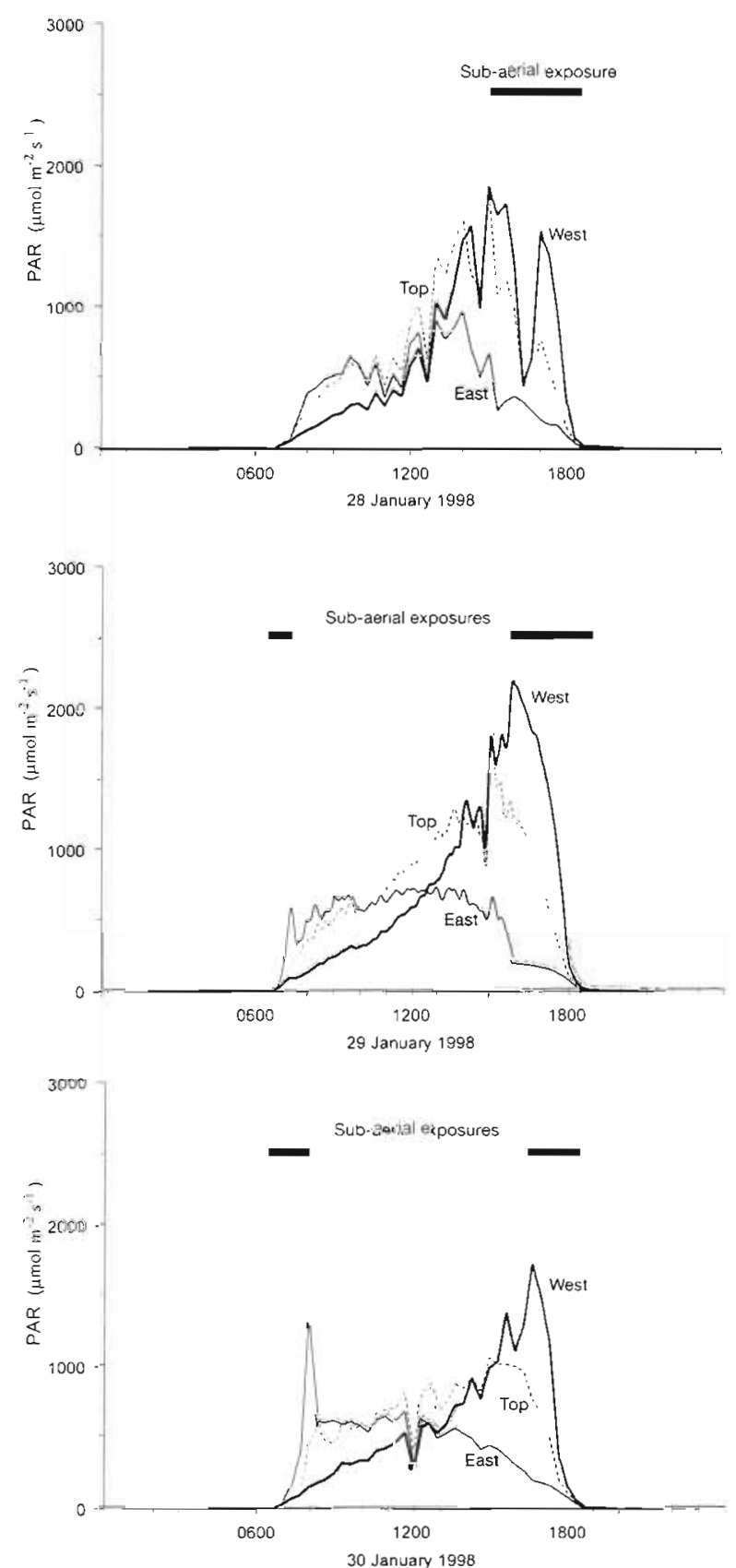
received by west surfaces, exceeding those received by east surfaces by an average 2 -fold. Irradiance levels on the west sides of corals also exceeded those on the upper surfaces of colonies in the early afternoon. This result may be explained by consideration of the position of the differently angled surfaces of the colony relative to the azimuth and altitude of the sun. During the early afternoon the west sides directly face the sun and as a result receive a relatively greater proportion of the direct irradiance in the solar beam than the horizontal upper surfaces.

As the spring tide sequence progressed, the time of sub-aerial exposure became later each day and consequently the risk of exposure of corals to damaging irradiances associated with a high sun altitude diminished, and the daily PAR dose received by the coral surfaces also decreased (Fig. 2).

\section{Chlorophyll fluorescence measurements}

Chlorophyll fluorescence measurements obtained from control and rotated corals are shown in Fig. 3. Dark-adapted $F_{\mathrm{v}} / F_{\mathrm{m}}$ values were lower on the west sides of control corals compared to east sides on all days of measurement. These low values indicate damage to PSII in symbiotic algae in the vicinity of the existing solar lesion, as they were obtained 6 to $12 \mathrm{~h}$ after coral collection when recovery from dynamic photoinhibition should have taken place. On 28 January, when irradiance was lower than preceding or subsequent days, dark-adapted $F_{\mathrm{v}} / F_{\mathrm{m}}$ values on the 'west' side of rotated corals were significantly lower $(\mathrm{p}<$ 0.0012 -tailed $t$-test) than measurements from similarly coloured tissues above or below the lesion on the west sides of control colonies, indicating marked damage on the 'west' sides of rotated corals compared to control colonies. $F_{\mathrm{v}} / F_{\mathrm{m}}$ values taken from the solar lesion area, on the 'east' sides of rotated corals, steadily climbed throughout the experiment from 0.48 on 26 January to 0.59 on 30 January, indicating recovery from photodamage.

In rotated corals, when $\Delta F / F_{m}$ results for 28 January were compared with dark-adapted $F_{\mathrm{v}} / F_{\mathrm{m}}$ data (Table 1) it was clear that $F_{v} / F_{\mathrm{m}}$ values for the 'west' sides were still low 6 to $12 \mathrm{~h}$ after collection, indicating photodamage on surfaces which were formerly orientated to the east. Indeed, by 30 January new lesions were forming on the 'west' sides of rotated corals. Interestingly, 'west' sides of rotated corals showed a steady decline in $F_{\mathrm{v}} / F_{\mathrm{m}}$ ratios throughout the experiment (Fig. 3), falling from 0.51 on 26 January to 0.44 on 28 January and 0.33 on 30 January. In contrast, west sides of control colonies, although showing evidence of photodamage at the outset of the experiment, appeared to show no further deterioration over the study period.

\section{Pigments}

There were no significant differences in algal chlorophyll $a$ or $c_{2}$ between east and west sides of control and rotated corals on any sampling date. Changes in the algal diatoxanthin content relative to the xanthophyll pool $(\mathrm{Dt} /[\mathrm{Dd}+\mathrm{Dt}]$ where $\mathrm{Dt}=$ diatoxanthin and $\mathrm{Dd}=$ diadinoxanthin, hereafter referred to as the xanthophyll ratio) were used as a measure of the protective interconversion of xanthophylls. In this experiment the xanthophyll ratio in all samples was strongly correlated to the PAR at the time of sample collection $(\mathrm{r}=$

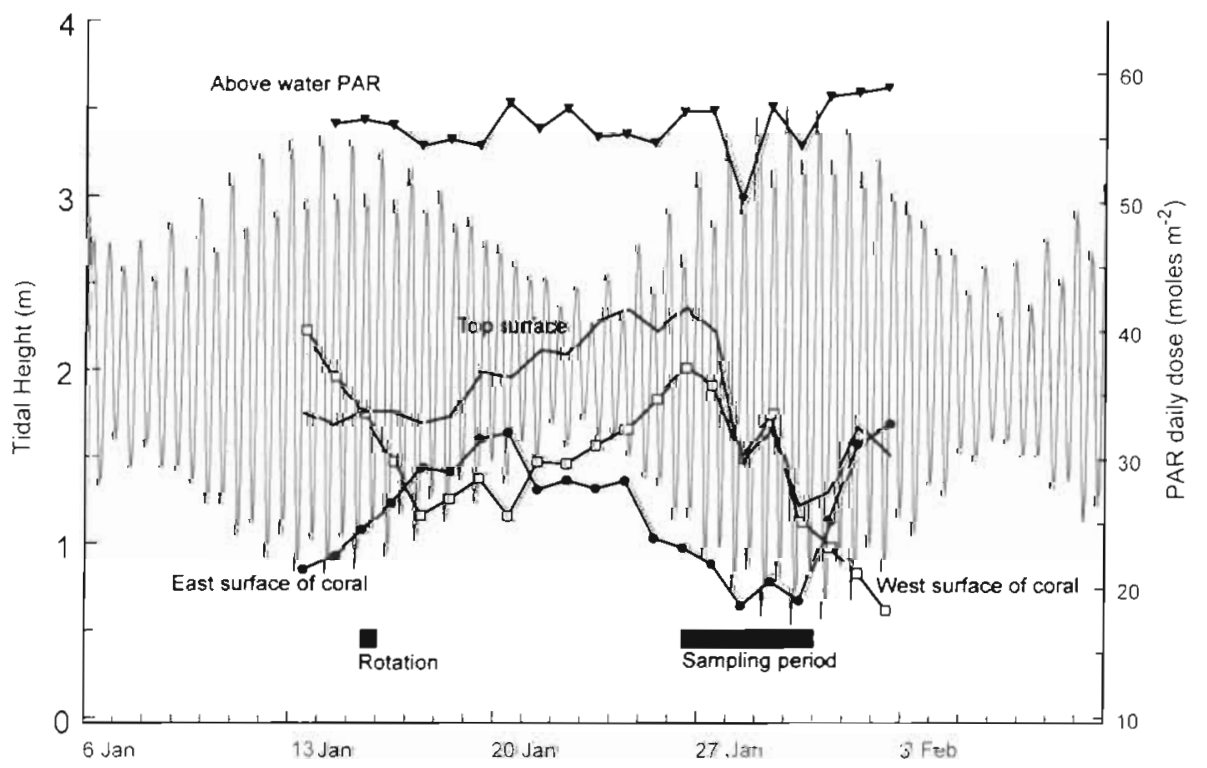

Fig. 2. Daily PAR dose $\left(\mathrm{mol} \mathrm{m}^{-2}\right)$ received by west, top, and east facing surfaces of colonies of Goniastrea aspera over the period 13 January to 3 February 1998 , together with the PAR daily dose above water. The tidal curve is shown from 6 January to 10 February. The dates of rotation and sampling periods are shown by the boxes 
Table 1. Goniastrea aspera. Chlorophyll fluorescence parameters measured on 28 January 1998 on 'west' and 'east' sides of rotated colonies, and from 4 random points ( 1 to 4 ) around the solar lesion on the 'east' side (means \pm 1 standard deviation shown, $\mathrm{n}=3$ in each case)

\begin{tabular}{|c|c|c|c|c|c|c|}
\hline \multirow{2}{*}{ Parameter } & \multicolumn{6}{|c|}{ Point of measurement } \\
\hline & 'West' & 'East' & 1 & 2 & 3 & 4 \\
\hline$\Delta F / F_{\mathrm{m}^{\prime}}$ & $0.33(0.009)$ & $0.47(0.08)$ & $0.54(0.06)$ & $0.53(0.03)$ & $0.55(0.03)$ & $0.56(0.05)$ \\
\hline$F_{\mathrm{v}} / F_{\mathrm{m}}$ & $0.44(0.02)$ & $0.51(0.03)$ & $0.53(0.04)$ & $0.55(0.009)$ & $0.55(0.03)$ & $0.57(0.01)$ \\
\hline
\end{tabular}

0.97, $n=36, p<0.0001$ ). As much as $94 \%$ of the variation $\left(\mathrm{r}^{2}=0.94\right)$ in xanthophyll ratio can therefore be explained by PAR received on the east and west sides of colonies at the time of sampling, irrespective of any manipulation of coral colonies. On 26 and 30 January when PAR irradiance on the west surfaces was high at the time of sampling (2199 and $1502 \mu \mathrm{mol} \mathrm{m} \mathrm{m}^{-2} \mathrm{~s}^{-1}$ respectively) compared to the east surfaces (394 and $182 \mu \mathrm{mol} \mathrm{m} \mathrm{m}^{-2} \mathrm{~s}^{-1}$ ), there were significant differences in xanthophyll ratios between east and west sides of both control and rotated corals $(\mathrm{p}<0.001$, paired 2 -tailed t-tests) (Fig. 4).

In contrast, on 28 January when west facing PAR irradiance was $472 \mu \mathrm{mol} \mathrm{m} \mathrm{m}^{-2} \mathrm{~s}^{-1}$ and east facing $300 \mu \mathrm{mol}$ $\mathrm{m}^{-2} \mathrm{~s}^{-1}$, there were no differences in xanthophyll ratios between the 2 surfaces in control colonies, but sig- nificant differences in the rotated colonies $(\mathrm{p}<0.001$, paired $t$-test). The rotated colonies also had significantly higher ratios on their 'west' sides compared to the west sides of controls $(p<0.02, t$-test).

\section{DISCUSSION}

By rotating coral colonies in this study, we were able to induce photodamage on the 'west' facing surface of the coral, at the same time as observing recovery from photodamage on the 'east' facing surface. Exposure of rotated corals to high solar radiation ultimately produced a solar lesion, or bleached area, on the coral faces newly oriented to the west. Parallel to this visible damage, chlorophyll fluorescence measurements $\left(F_{\mathrm{v}} / F_{\mathrm{m}}\right)$ on these faces showed a marked decline in photochemical efficiency over the $5 \mathrm{~d}$ study. From earlier work (Le Tissier \& Brown 1996), solar lesion formation has been shown to involve the loss of surficial algae as opposed to those located deeper in the coral polyp which may be shadeadapted. Because the chlorophyll fluorescence technique used here preferentially sampled the top layers of photosynthetic
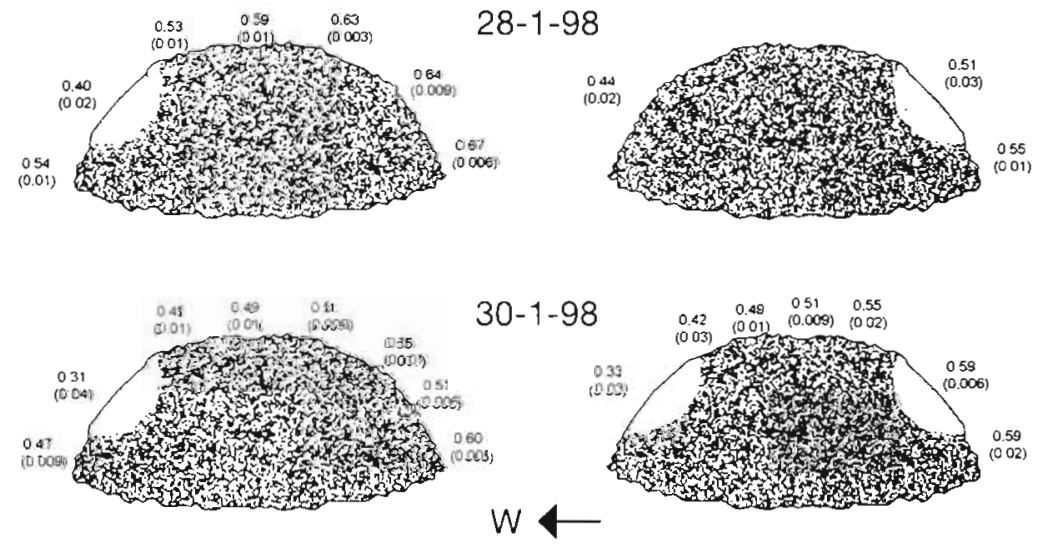

Fig. 3. Goniastrea aspera. Measurements of photochemical efficiency $\left(F_{\mathrm{v}} / F_{\mathrm{T}}\right)$ of PSII on surfaces of control and rotated corals on 26,28 and 30 January 1998. Mean values are shown \pm standard deviation $(n=3)$. The lightly stippled areas on the colony surfaces represent visible solar lesions (bleached areas)

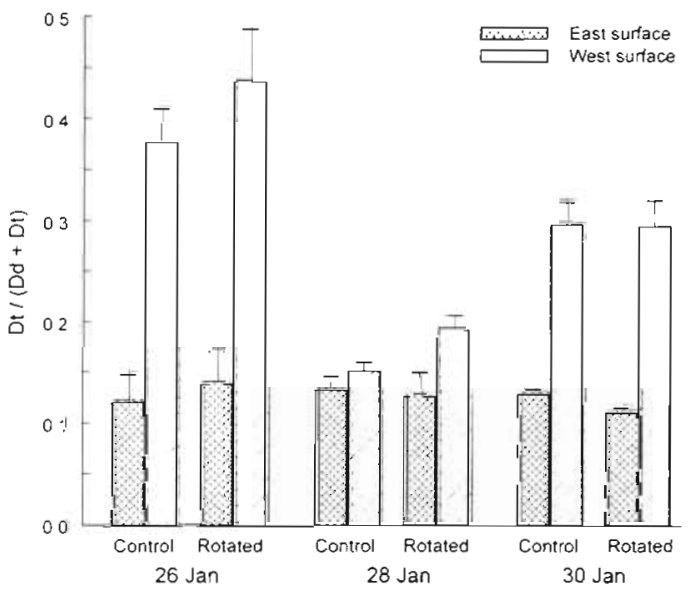

Fig. 4. Xanthophyll ratio $D t /(D d+D t)$ in east and west surfaces of control, and 'east' and 'west' surfaces of rotated corals on 26, 28 and 30 January 1998 
tissues (Ralph et al. 1999) it could be argued that the changes in photosynthetic efficiency recorded over time were a function of sampling from a changing population of algae. The expected trend would be to sample from a population of algae which had previously been in shaded positions in the polyp, and thus to record an increase rather than a decrease in photochemical efficiency (Ralph et al. 1999). The fact that a decline in $F_{\mathrm{v}} / F_{\mathrm{m}}$ was observed is therefore likely to be an underestimate of the full extent of the photodamage which was induced.

A similar, but reverse, argument might be expected to apply to the photorecovery on 'east' facing surfaces of corals, i.e. sampling of a population of older damaged algae at the beginning of the experiment which then progressively divided to form new algae as the experiment progressed. The doubling time for symbiotic algae in Goniastrea aspera from Phuket has been estimated as $\sim 7.4 \mathrm{~d}$ (Zamani 1995), which suggests that algal densities could have been partly replenished in shaded 'east' sides of rotated colonies during the experimental period. Thus the recovery of photosynthetic efficiency observed may have involved either recovery of existing algal cells and/or the formation of recently divided cells, under less damaging environmental conditions on shaded east surfaces of corals.

The failure of symbiotic algae on 'west' faces of rotated corals to recover full photosynthetic activity after overnight dark adaptation was likely due to 'chronic' photoinhibition. Similar effects have been described in higher plants (Osmund 1994) and algae (reviewed by Franklin \& Forster 1997) after sustained exposure to high photon fluxes.

The pattern of change in $F_{\mathrm{v}} / F_{\mathrm{m}}$ measurements in the corals over the sampling period, and the changes in solar radiation over that time, suggest that damage and partial recovery to the PSII reaction centres probably operates over a timescale of $24 \mathrm{~h}$ or less. In order to examine this proposition in more detail, $F_{\mathrm{v}} / F_{\mathrm{m}}$ values for the differently oriented surfaces of control colonies were compared to the PAR dose for each surface during the hours of daylight before the corals were collected from the field. A significant negative correlation ( $\mathrm{r}=$ $-0.43, p=0.012, n=33$ ) demonstrates that increases in PAR dose appeared to be leading to chronic photoinhibition, although the wide $95 \%$ confidence interval $(-0.67$ to -0.10$)$ and low $\mathrm{r}^{2}(18.6 \%)$ indicate that the relationship is relatively weak. On the basis that visible solar lesions are only induced by periods of particularly high irradiance (Brown et al. 1994a) rather than dose alone, this analysis was taken 1 step further. The dependence of decreasing $F_{\mathrm{v}} / F_{\mathrm{m}}$ was examined for doses of PAR where the irradiance was in excess of $1000 \mu \mathrm{mol}$ $\mathrm{m}^{-2} \mathrm{~s}^{-1}$. In this case, the correlation strengthened $(\mathrm{r}=$ $-0.48, r^{2}=22.7 \%, p=0.0005, n=33,95 \%$ confidence interval $=-0.71$ to -0.16$)$, suggesting that PSIl damage was a factor of high dose and high irradiance in combination. Similar conclusions have been reached for higher plants when examining the effects of sunflecks and light gaps on photoinhibition (Pearcy 1994).

Interestingly, while photodamage steadily increased over the period of measurements on the 'west' sides of rotated corals, damage on west sides of control corals remained steady. Earlier work (Ambarsari et al. 1997) has shown that solar lesions on western faces of corals have an increased xanthophyll pool (relative to chlorophyll a), a greater conversion of diadinoxanthin to diatoxanthin, and a higher proportion of $\beta$-carotene than coloured tissue from western and eastern surfaces. All these factors may be significant in arresting further damage. An additional photoprotective mechanism is host tissue retraction, which has been described in other intertidal corals as increasing solar PAR reflectance by as much as $10 \%$, as well as providing shading of symbiotic algae (Brown et al. 1994b). Tissue retraction patterns in rotated 'east' and 'west' surfaces were observed to be very different during the course of the experiment, with 'east' surfaces showing strong retraction despite exposure to low solar radiation, and 'west' surfaces only partial retraction despite exposure to high solar radiation. Such a pattern, which is characteristic behaviour of coral polyps in their pre-manipulation positions, persisted for at least $3 \mathrm{~d}$ of the spring tide sequence and may have had some part to play in the different responses elicited by the differently orientated surfaces. Similar diurnal and tidal rhythms in anthozoans in response to light have been described by Batham \& Pantin (1950a,b), with a daily rhythm of expansion and contraction in Metridium senile being noted for more than $3 \mathrm{wk}$ in complete darkness. Other retained rhythms which have been demonstrated in cnidarians include retraction in the soft coral Alcyonium (Hickson 1895) and the hydroid Cavernularia (Mori 1959, 1960).

Recovery of photosynthetic efficiency in damaged surfaces of rotated corals was slow compared to that observed in higher plants maintained under low light following photodamage (Pearcy 1994). However, the delayed recovery in the present study may be explained by the environmental microclimate experienced by 'east' sides immediately following rotation. On these surfaces, very limited recovery of photosynthetic efficiency was observed over a $10 \mathrm{~d}$ period (i.e $5 \mathrm{~d}$ of spring tides when corals were sub-aerially exposed at dawn and dusk and $5 \mathrm{~d}$ of neap tides when corals were not uncovered but in less than $20 \mathrm{~cm}$ water at midday). Over the first $8 \mathrm{~d}$ of this period, sensor information indicated that the PAR dose received by 'east' and 'west' sides of colonies had been similar, with 'east' sides initially receiving higher doses than 
'west' during sub-aerial exposure on early morning spring tides (Fig. 2). For 'east' sides, substantially lower PAR irradiance and dose, conducive to recovery, did not occur until 25 January, just $24 \mathrm{~h}$ before the first chlorophyll fluorescence measurements were taken. During the period 25 to 30 January, marked recovery of photosystem efficiency was noted on 'east' sides of rotated corals, a process which would require synthesis of the $\mathrm{D}_{1}$ protein of PSII. Such synthesis is generally optimal under low irradiance (Krause \& Weiss 1991). Recent work by Warner et al. (1999) with cultured symbiotic algae suggests that $D_{1}$ turnover rates may be much slower than those reported in higher plants.

This study has highlighted the susceptibility of photosynthetic processes to solar bleaching, and demonstrated both damage and recovery of PSII during manipulation of Goniastrea aspera in the field. The timescale for photodamage to be elicited is very short and may amount to $3 \mathrm{~h}$ of exposure to high PAR irradiance and high dose in combination. Recovery from significant photodamage, under field conditions, may take much longer. In the present study, at least $5 \mathrm{~d}$ of reduced solar radiation were needed before a marked recovery of photosynthetic efficiency was noted. Clearly it is important to understand not only the mechanisms underlying damage and recovery of PSII, but also the dynamics of these processes, if the differing bleaching susceptibilities of reef corals are to be properly understood.

Acknowledgements. We thank the Director and staff of the Phuket Marine Biological Center for their support, particularly Dr Hansa Chansang, Mr Sambat Poovachiranon, Mr Niphon Phongsuwan, and Mr Ukkrit Satapoomin. We are also grateful to the Natural Environment Research Council and the University of Newcastle Research Fund for financial support.

\section{LITERATURE CITED}

Ambarsari I, Brown BE, Barlow RG, Britton G, Cummings D (1997) Fluctuations in algal chlorophyll and carotenoid pigments during solar bleaching in the coral Goniastrea aspera at Phuket. Thailand. Mar Ecol Prog Ser 159: 303-307

Batham EJ, Pantin CFA (1950a) Inherent activity in the seaanemone, Metridium senile (L.). J Exp Biol 27:290-301

Batham EJ, Pantin CFA (1950b) Phases of activity in the seaanemone, Metridium senile (L.), and their relation to external stimuli. J Exp Biol 27:377-399

Brown BE (1997) Coral bleaching: causes and consequences. Coral Reefs 16:S129-S138

Brown BE, Dunne RP, Scoffin TP, Le Tissier MDA (1994a) Solar damage in intertidal corals. Mar Ecol Prog Ser 105: 219-230

Brown BE, Le Tissier MDA, Dunne RP (1994b) Tissue retraction in the scleractinian coral Coeloseris mayeri, its effect upon pigmentation, and preliminary implications for heat balance. Mar Ecol Prog Ser 105:209-218
Brown BE, Ambarsari I, Warner ME, Fitt WK, Dunne RP, Gibb SW, Cummings DG (1999) Diurnal changes in photochemical efficiency and xanthophyll concentrations in shallow water reef corals: evidence for photoinhibition and photoprotection. Coral Reefs 18:99-105

Buskirk RE, Taylor FW, O'Brien WP, Maillet P, Gilpin L (1981) Seasonal growth patterns and mortality of corals in the New Hebrides (Vanuatu). Proc 4th Int Coral Reef Symp 2:197-200

Chambers DP, Tapley BD, Stewart RH (1999) Anomalous warming in the Indian Ocean coincident with El Niño. $J$ Geophys Res 104:3035-3047

Dove SG, Takabayashi M, Hoegh-Guldberg O (1995) Isolation and partial characterization of the pink and blue pigments of pocilloporid and acroporid corals. Biol Bull 189: $288-297$

Dunlap WC, Shick JM (1998) Ultraviolet radiation-absorbing mycosporine-like amino acids in coral reef organisms: a biochemical and environmental perspective. J Phycol 34 $418-430$

Franklin LA, Forster RM (1997) The changing irradiance environment: consequences for marine macrophyte physiology, productivity and ecology. Eur J Phycol 32:207-232

Hickson SJ (1895) The anatomy of Alcyonium digitatum. Q J Microsc Sci 37:343-388

Iglesias-Prieto R, Matta JL, Robins WA, Trench RK (1992) Photosynthetic response to elevated-temperature in the symbiotic dinoflagellate Symbiodinium microadriaticum in culture. Proc Natl Acad Sci 89:302-305

Jones RJ, Hoegh-Guldberg O, Larkum AWD, Schreiber U (1998) Temperature-induced bleaching of corals begins with impairment of the $\mathrm{CO}_{2}$ fixation mechanism in zooxanthellae. Plant Cell Environ 21:1219-1230

Krause GH, Weis E (1991) Chlorophyll fluorescence and photosynthesis: the basics. Annu Rev Plant Physiol Plant Mol Biol 42:313-349

Lesser MP (1997) Oxidative stress causes coral bleaching during exposure to elevated temperatures. Coral Reefs 16 : $187-192$

Lesser MP, Stochaj WR, Tapley DW, Shick JM (1990) Bleaching in coral reef anthozoans: effects of irradiance, ultraviolet radiation, and temperature on the activities of protective enzymes against active oxygen. Coral Reefs 8: 225-232

Le Tissier MDA, Brown BE (1996) Dynamics of solar bleaching in the intertidal reef coral Goniastrea aspera at Ko Phuket, Thailand. Mar Ecol Prog Ser 136:235-244

Mori S (1959) On the general knowledge of daily rhythmic activity of sea-pen, Cavernularia obesa Valenciernes. Bull Mar Biol Asamuchi 9:157-160

Mori S (1960) Influence of environmental and physiological factors on the daily rhythmic activity of a sea-pen. Cold Spring Harbor Symp Quant Biol 25:333-344

Osmund CB (1994) What is photoinhibition? Some insights from comparisons of shade and sun plants. In: Baker NR, Bowyer JR (eds) Photoinhibition of photosynthesis: from molecular mechanisms to the field. Bios Scientific Publishers, Oxford, p 1-24

Pearcy RW (1994) Photosynthetic response to sunflecks and light gaps: mechanisms and constraints. In: Baker NR, Bowyer JR (eds) Photoinhibition of photosynthesis. Bios Scientific Publishers, Oxford, p 255-271

Ralph PJ, Gademann R, Larkum AWD, Schreiber U (1999) In situ underwater measurements of photosynthetic activity of coral zooxanthellae and other reef-dwelling dinoflagellate endosymbionts. Mar Ecol Prog Ser 180: $139-147$ 
Tyler JE, Smith RC (1970) Measurement of spectral irradiance underwater. Gordon and Breach Science Publishers, New York

Veron JEN (1986) Corals of Australia and the Indo-Pacific. Angus and Robertson Publishers, London

Warner ME, Fitt WK, Schmidt GW (1996) The effects of elevated temperature on the photosynthetic efficiency of zooxanthellae in hospite from four different species of reef coral: a novel approach. Plant Cell Environ 19:291-299

Warner ME, Fitt WK, Schmidt GW (1999) Damage to Photo-

Editorial responsibility: Otto Kinne (Editor),

Oldendorf/Luhe, Germany system II in symbiotic dinoflagellates: a determinant of coral bleaching. Proc Natl Acad Sci 96:8007-8012

Yonge CM (1940) The biology of reef-building corals. Sci Rep Gt Barrier Reef Exped 1928-1929. Br Mus Nat Hist 1: $353-391$

Zamani NP (1995) Effects of environmental stress on cell division and other cellular parameters on zooxanthellae in the tropical symbiotic anemone Heteractis malu Haddon and Shackelton. PhD dissertation, University of Newcastle upon Tyne

Submitted: July 20, 1999; Accepted: September 22, 1999

Proofs received from author(s): March 7, 2000 